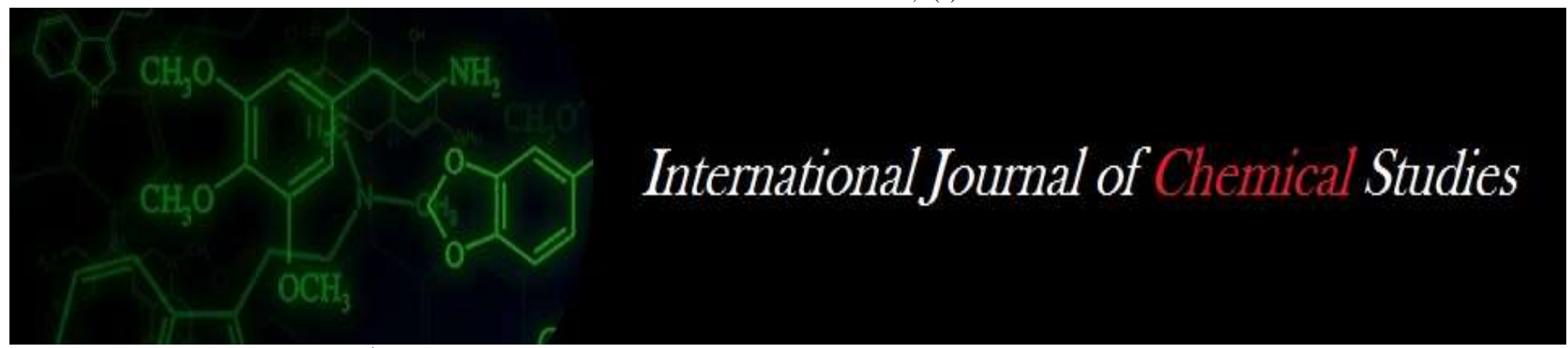

P-ISSN: 2349-8528

E-ISSN: 2321-4902

www.chemijournal.com

IJCS 2020; 8(6): 1759-1764

(C) 2020 IJCS

Received: 23-09-2020

Accepted: 18-11-2020

\section{Chanchal Nikam}

Ph. D Scholar, Department of

Vegetable Science, Dr. P.D.K.V.

Akola, Maharashtra, India

VS Kale

Professor, Department of Vegetable Science, Dr. P.D.K.V., Akola, Maharashtra, India

\section{PK Nagre}

Dean, Faculty of Horticulture and Associate Dean, College of Horticulture, Dr. P.D.K.V., Akola, Maharashtra, India
Corresponding Author:

Chanchal Nikam

Ph. D Scholar, Department of

Vegetable Science, Dr. P.D.K.V.,

Akola, Maharashtra, India

\section{Studies on effect of different mulches and fertigation on growth and yield of turmeric (Curcuma longa $\mathrm{L}$.)}

\author{
Chanchal Nikam, VS Kale and PK Nagre
}

DOI: https://doi.org/10.22271/chemi.2020.v8.i6y.11022

\begin{abstract}
A field experiment was carried out in the Horticulture Department, Dr. Panjabrao Deshmukh Krishi Vidyapeeth, Akola (M.S.) during the two years (2017-18 and 2018-19) for studying the effect of different mulches and fertigation on growth and yield of turmeric (Curcuma longa L.). The treatment consists of combinations of three mulches (without mulch, soybean straw mulch, and silver polythene mulch) with five fertigation schedule (control $-100 \%$ RDF through soil application, 15, 8, 5 and 4 days interval in 10, 20, 30 and 40 splits through fertigation @ 80\% RDF) and was arranged in Strip Plot Design with three replicates. The results of the experiment revealed that in respect of growth parameters viz. plant height (at 180 days after planting), number of tillers plant ${ }^{-1}$ and leaf area (at 180 days after planting) were recorded maximum in soybean straw mulch and 30 splits with 5 days interval through fertigation @80\% recommended dose of fertilizer (RDF). In respect of yield parameters, maximum number of mother rhizome and fingers plant ${ }^{-1}$, length of mother rhizome and primary fingers, yield plant ${ }^{-1}$, yield $(\mathrm{q} / \mathrm{ha})$ and dry matter plant ${ }^{-1}$ were recorded in soybean straw mulch and 30 splits with 5 days interval through fertigation@80\% RDF.
\end{abstract}

Keywords: Fertigation schedules, growth, mulching, turmeric, and yield

\section{Introduction}

Turmeric (Curcuma longa L.) is a perennial herbaceous plant belonging to the Zingiberaceae family. It is most important commercial spice crops. Origin of turmeric is tropical South- East Asia. Turmeric is called the "spice of life" as well as the "golden spice". Turmeric was consumed in multidisciplinary, such as spice, food, cosmetics, and medicine. It is a dye, with varied usages in cosmetic and drug industries. It is used as a medicinal for external application and taken internally as a stimulant. "Kum-kum" is also a by-product of turmeric. Turmeric is used in cosmetic, pharmaceutical, confectionary and food industries. Besides spice, turmeric has a wide range of medicinal values such as stimulant, blood purifier, tonic as a carminative, remedy for skin diseases, itches, pains and anthelmintic (Srimal 1997) ${ }^{[26]}$.

Turmeric is widely cultivated in India, Sri Lanka, Bangladesh, China, Thailand, Cambodia, Taiwan, Malaysia, Peru, Indonesia and Pakistan. India is the topmost country in the world for turmeric production and consumption also exports and accounts for $80 \%$ of the world's turmeric production. Turmeric is cultivated on 238 thousand hectares with a production of 1133 thousand metric tonnes in Andhra Pradesh, Tamil Nadu, Odisha, Kerala, Maharashtra, West Bengal and north-eastern states of India (Anonymous 2017) ${ }^{[1]}$.

The application of mulch reduces evaporation losses, regulates the soil temperature, suppresses weeds and protects the germinating rhizomes from drying out, especially during the early growth phase of hot and dry months (May and June). Philip et al. (1981) ${ }^{[18]}$ and Kumar et al. (2008) ${ }^{[14]}$ observed that mulching improved rhizome sprouting and considerably reduced weed growth by conserving soil moisture. Application of straw mulch had a favorable effect on growth and yield parameters compared to without mulch, which could be explained by rapid emergence, early establishment of the crop and greater interception of light (Singh and Randhawa, 1988) ${ }^{[23]}$. Mulch also improves water retention in the soil and microflora and fauna in the soil, and reduces wind velocity at the soil surface in arid regions (Kay, 1978; Jalota and Prihar, 1998) ${ }^{[13,10]}$. 
Turmeric is a nutrient loving plant and removes a large number of nutrients from the soil. Sufficient amount of nutrients must be applied to meet its nutritional need and achieve higher yields (Dubey and Singh, 2004) ${ }^{[4]}$. A drip irrigation system is a very efficient method of providing water to plant (Banker et al., 1993) ${ }^{[2]}$. Fertigation through drip irrigation facilitates the precise application of fertilizers. It delivers nutrients to the roots where it can be effectively and lead to increased nutrient absorption and utilization efficiency. (Elfving, 1982) [5]. Fertigation allows the application of a nutrient directly at the site of a high concentration of active roots and according to the needs of the crop. Scheduling fertilizer applications as needed offers the potential to reduce nutrient loss associated with conventional application. Methods that depend on soil as a nutrient reservoir thus increasing the efficiency of nutrient use. Fertilizer savings through fertigation can be to the tune of 25 $50 \%$ (Haynes, 1985) ${ }^{[8]}$.

\section{Material and Methods}

An experiment was carried out at the main garden of the Horticultural Department, Dr. Panjabrao Deshmukh Krishi Vidyapeeth, Akola, during 2017-18 and 2018-19. The soil at the experimental site had $7.4 \mathrm{pH}, 0.56 \%$ organic carbon, $155.84 \mathrm{~kg} / \mathrm{ha}$ available nitrogen, $23.56 \mathrm{~kg}$ available phosphorus, and $448.42 \mathrm{~kg} / \mathrm{ha}$ available potassium. The experiment was designed in Strip Plot Design with 3 repetitions and 15 treatment combinations. The treatment included three levels of mulching i.e. control (without mulch), soybean straw mulch, and silver polythene mulch with five levels of fertigation schedule i.e. control (100\% RDF through soil application), 10 no. of splits with 15 days interval, 20 no. of splits with 8 days interval, 30 no. of splits with 5 days interval, and 40 no. of splits with 4 days interval through fertigation@80\% RDF. The land was ploughed thoroughly and brought fine tilth. At the time of the last ploughing, FYM was applied at $30 \mathrm{t} \mathrm{ha}^{-1}$. After levelling, raised beds were prepared with dimensions of $2.8 \mathrm{~m}$ length, $0.6 \mathrm{~m}$ width, $30 \mathrm{~cm}$ height, and $60 \mathrm{~cm}$ path between two raised beds. Mother rhizomes of turmeric var. PDKV Waigaon weighing about 50 $\mathrm{g}$ were selected for planting. Planting was taken during June 2017 and 2018. The treatments receiving drip irrigation, drip laterals were laid along the length of each bed at the center. Two rows of plants per raised bed were laid out with a spacing of $30 \mathrm{~cm}$ between rows and $30 \mathrm{~cm}$ between plants within a row. A raised bed was taken mulched with silver polythene of $50 \mu$ thickness and fully matured soybean straw mulch ( $5 \mathrm{t} / \mathrm{ha})$ after planting and the thickness of straw mulch was $5 \mathrm{~cm}$ from the above ground level. The mulch was provided in between two rows of the crop. The recommended dose of fertilizer was 200:100:100 kg/ha N, $\mathrm{P}_{2} \mathrm{O}_{5}$, and $\mathrm{K}_{2} \mathrm{O}$. Basal soil application of fertilizer $100 \%$ respectively was carried out in $F_{1}$ treatments and up to $F_{2}$ to $F_{5}$ treatments (80 $\%$ RDF through fertigation); fertigation was started at 35 days after sowing up to plan of fertigation schedule by automatic fertigation unit as per treatment. Fertigation was carried out using water-soluble fertilizers (Urea and 19:19:19 complex), all agronomic practices, and plant protection measures. Harvesting was done during February 2018 and 2019. Observation of different growth and yield parameters was recorded from five plants randomly sampled from each treatment.

\section{Results and Discussion}

The results obtained from the present investigation are presented below based on the pooled mean of two years of experimentation (2017-18 and 2018-19).

\section{Effect of mulching}

\section{Growth parameters}

The growth parameters included plant height at 180 days after planting (DAP), the number of leaves plant ${ }^{-1}$ (at 120 DAP), leaf area (at $180 \mathrm{DAP}$ ), and the number of tillers plant ${ }^{-1}$ at harvest and presented in table 1.

The data showed significant differences between treatments for plant height. Significantly maximum plant height (93.66 $\mathrm{cm}$ ) was recorded in $\mathrm{M}_{2}$ i.e. soybean straw mulch which was significantly superior over the rest of all the treatments. This was followed by treatment $\mathrm{M}_{3}$ i.e. silver polythene mulch. However, significantly minimum plant height was registered in $\mathrm{M}_{1}$ i.e. control (without mulch).

The application of mulch had a beneficial effect on plant height by altering the soil environment by maintaining a favorable temperature, increasing soil moisture, increasing nutrient availability and improving weed control. The mulch application, which produced larger plants, was also discussed by Mohanty et al. (1991); Gill et al. (1999); Junior et al. (2005); Swain et al. (2007); Manhas (2009) and Singh et al. (2016) ${ }^{[17,6,11,27,16,24]}$ in turmeric. Rair et al. (2011) ${ }^{[20]}$ have reported that relatively more height in the plot mulched with straw over plastic in turmeric.

The data revealed significant differences among the treatments in respect number of tillers plant ${ }^{-1}$ and leaf area. Significantly maximum number of tillers plant ${ }^{-1}$ and leaf area were recorded in $\mathrm{M}_{2}$ i.e. soybean straw mulch (1.76 and $255.73 \mathrm{~cm}^{2}$, respectively) and was found statistically at par with the treatment $\mathrm{M}_{3}$ i.e. silver polythene mulch. However, the significantly minimum number of tillers plant ${ }^{-1}$ and leaf area was recorded in $M_{1}$ i.e. control (without mulch).

Mulched plots produced a higher number of tillers plant ${ }^{-1}$ than plots that were not mulched. This could be because the mulch was applied to plots that produced better growth and development for the plant. Singh and Randhawa (1988) and Singh et al. (2016) ${ }^{[23,24]}$ have reported an increase in the number of plant ${ }^{-1}$ tillers due to mulch. Earlier and higher spouting of rhizomes, in straw, mulched plots gave the crop dominance over weeds, and as a result, the crop used more nutrients from the soil and produced more leaf surface than non-mulched plots. The leaf area is directly related to the number of leaves and plays an important role in photosynthesis in plants. A higher number of tillers and leaves could have resulted in more leaf area plant $^{-1}$ under mulched areas. These results were in close agreement with the results of Gupta, and Awasthi (1997) ${ }^{[7]}$ reported that the beneficial effect of mulching on the leaf area of ginger.

The data revealed non-significant among the treatments for the number of leaves plant ${ }^{-1}$.

\section{Yield parameters}

The observation recorded on yield parameters are given in table 2 (a) and 2 (b). Significant differences were recorded among the treatments for number mother rhizome plant ${ }^{-1}$, yield plant ${ }^{-1}$, yield (q/ha), and dry matter plant ${ }^{-1}$ at harvest. Significantly maximum number mother rhizome plant ${ }^{-1}$, yield plant $^{-1}$, yield (q/ha), and dry matter plant ${ }^{-1}$ was recorded in $\mathrm{M}_{2}$ i.e. soybean straw mulch $(1.55,456.28 \mathrm{~g}, 337.98 \mathrm{q} / \mathrm{ha}$, and $32.61 \mathrm{~g}$, respectively) which was significantly superior over rest of all the treatments. This was followed by treatment $\mathrm{M}_{3}$ i.e. silver polythene mulch. However, significantly minimum number mother rhizome plant $^{-1}$, yield plant ${ }^{-1}$, yield ( $\mathrm{q} / \mathrm{ha}$ ), and dry matter plant ${ }^{-1}$ was registered in $M_{1}$ i.e. control (without mulch). 
Mulched plots produced a higher number of mother rhizome as compared to without mulch. This might be due to the mulched plots produced better growth and development of the plant and it helps to increase the number of mother rhizome. The application of straw mulch increased the yield of turmeric significantly as compared to no mulch. Soybean straw and silver polythene mulches have significantly increased the rhizome yield (q/ha) (27.37\% and $12.80 \%$ over control, respectively pooled). The higher yield with organic mulch was due to reduced vapor loss, erosion, modified temperature, retention of moisture, the addition of nutrients to the soil, reduced weed emergence, and nutrient loss. The results of the present investigation are in agreement with the finding of Mohanty et al. (1991) and Gill et al. (1999) ${ }^{[17,6]}$ in turmeric,

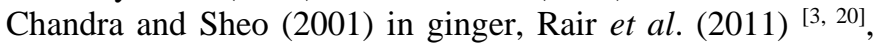
and Kaur and Brar (2016) ${ }^{[12]}$ in turmeric. Total dry matter production of turmeric at harvest was significantly higher in plots mulched with soybean straw and silver polythene mulch than non-mulched plots. Higher plant height, number of tillers, and leaf area production as reported earlier caused higher dry matter production in mulched plants. Similar results were obtained by Indulekha and Thomas (2018) ${ }^{[9]}$ in turmeric.

The data revealed significant differences among the treatments in respect number of fingers plant ${ }^{-1}$, length of mother rhizome, and primary fingers at harvest. Significantly maximum number of fingers plant ${ }^{-1}$, length of mother rhizome and primary fingers was recorded in $\mathbf{M}_{2}$ i.e. soybean straw mulch $(12.48,9.29 \mathrm{~cm}$, and $9.37 \mathrm{~cm}$ respectively) and was found statistically at par with the treatment $\mathrm{M}_{3}$ i.e. silver polythene mulch. However, the significantly minimum number of fingers plant ${ }^{-1}$, length of mother rhizome, and primary fingers were registered in $M_{1}$ i.e. control (without mulch).

The application of soybean straw mulch conserves moisture and lowers soil temperature as compared to without mulch of turmeric and this might have resulted in early and greater emergence of the crop and better establishment of the plants. The application of mulch delayed the emergence of weeds and would have also had a smothering effect on the number of fingers plant ${ }^{-1}$ of turmeric. Present findings are supported by that of Singh (1992) and Gill et al. (1999) ${ }^{[25,6]}$ in turmeric. The application straw mulch conserves moisture and modifying temperature regime in the crop environment as compared to without mulch of turmeric and this might have resulted in increased production of more assimilates and their transportation to sink (rhizome) it helps to increased the length of mother rhizome and primary fingers. Similar results were reported by Roy and Wamanan (1988) and Kushwah et al. (2013) ${ }^{[21,15]}$ in ginger.

The data revealed non-significant among the treatments in respect of girth of mother rhizome and primary fingers at harvest.

Table 1: Effect of different mulches and fertigation scheduling on growth parameters of turmeric

\begin{tabular}{|c|c|c|c|c|c|c|c|c|c|c|c|c|}
\hline \multirow[t]{2}{*}{ Treatments } & \multicolumn{3}{|c|}{ Plant height at 180 DAP } & \multicolumn{3}{|c|}{ Number of leaves plant ${ }^{-1}$ at 120 DAP } & \multicolumn{3}{|c|}{ Leaf area at 180 DAP } & \multicolumn{3}{|c|}{ Number of tillers plant ${ }^{-1}$} \\
\hline & 2017-18 & 2018-19 & Pooled & 2017-18 & 2018-19 & Pooled & 2017-18 & 2018-19 & Pooled & 2017-18 & 2018-19 & Pooled \\
\hline \multicolumn{13}{|c|}{ Factor A-Different mulches (M) } \\
\hline $\mathrm{M}_{1}$ & 74.76 & 85.74 & 80.25 & 13.06 & 15.03 & 14.05 & 185.14 & 211.30 & 198.22 & 0.89 & 1.36 & 1.13 \\
\hline $\mathrm{M}_{2}$ & 89.30 & 98.02 & 93.66 & 15.94 & 18.20 & 17.07 & \begin{tabular}{|l|}
241.78 \\
\end{tabular} & 269.67 & 255.73 & 1.45 & 2.06 & 1.76 \\
\hline $\mathrm{M}_{3}$ & 82.70 & 91.56 & 87.13 & 14.01 & 16.44 & 15.23 & 214.08 & 224.24 & 219.16 & 1.23 & 1.61 & 1.42 \\
\hline$F^{\prime}$ test & Sig. & Sig. & Sig. & NS & NS & NS & Sig. & Sig. & Sig. & Sig. & Sig. & Sig. \\
\hline $\mathrm{SE}(\mathrm{m}) \pm$ & 2.66 & 1.37 & 1.45 & 0.62 & 0.99 & 0.58 & 10.35 & 11.39 & 9.94 & 0.06 & 0.13 & 0.07 \\
\hline $\mathrm{CD}$ at $5 \%$ & 10.44 & 5.37 & 5.69 & - & - & - & 40.62 & 44.71 & 39.05 & 0.24 & 0.52 & 0.28 \\
\hline \multicolumn{13}{|c|}{ Factor B -Fertigation scheduling (F) } \\
\hline $\mathrm{F}_{1}$ & 69.62 & 83.49 & 76.55 & 12.57 & 13.52 & 13.04 & 179.52 & 202.62 & 191.07 & 0.80 & 1.22 & 1.01 \\
\hline $\mathrm{F}_{2}$ & 75.91 & 85.39 & 80.65 & 13.51 & 14.87 & 14.19 & 197.72 & 221.12 & 209.42 & 1.04 & 1.44 & 1.24 \\
\hline $\mathrm{F}_{3}$ & 80.67 & 91.83 & 86.25 & 14.27 & 16.89 & 15.58 & 215.55 & 233.91 & 224.73 & 1.18 & 1.69 & 1.43 \\
\hline $\mathrm{F}_{4}$ & 94.73 & 100.72 & 97.73 & 16.50 & 19.43 & 17.96 & 244.87 & 264.65 & 254.76 & 1.56 & 2.11 & 1.83 \\
\hline $\mathrm{F}_{5}$ & 90.33 & 97.44 & 93.88 & 14.86 & 18.09 & 16.47 & 230.68 & 253.06 & 241.87 & 1.38 & 1.92 & 1.65 \\
\hline$F^{\prime}$ test & Sig. & Sig. & Sig. & Sig. & Sig. & Sig. & Sig. & Sig. & Sig. & Sig. & Sig. & Sig. \\
\hline $\mathrm{SE}(\mathrm{m}) \pm$ & 2.81 & 2.5 & 1.63 & 0.5 & 0.89 & 0.54 & 9.57 & 7.87 & 7.4 & 0.12 & 0.08 & 0.07 \\
\hline CD at $5 \%$ & 9.15 & 8.15 & 5.32 & 1.62 & 2.9 & 1.75 & 31.21 & 25.67 & 24.12 & 0.38 & 0.28 & 0.24 \\
\hline \multicolumn{13}{|c|}{ Interaction (M X F) } \\
\hline $\mathrm{F}^{\prime}$ test & NS & NS & NS & Sig. & Sig. & Sig. & NS & NS & NS & NS & NS & NS \\
\hline $\mathrm{SE}(\mathrm{m}) \pm$ & 3.84 & 3.39 & 2.51 & 0.57 & 0.64 & 0.45 & 18.43 & 16.38 & 13.03 & 0.25 & 0.37 & 0.23 \\
\hline $\mathrm{CD}$ at $5 \%$ & - & - & - & 1.7 & 1.93 & 1.35 & - & - & - & - & - & - \\
\hline
\end{tabular}

$\mathrm{M}_{1-}$ Control (without mulch), $\mathrm{M}_{2}$-Soybean straw mulch, M3-Silver polythene mulch, F1-Control (100\% RDF through soil application), F2- 15 days interval, $\mathrm{F}_{3}-8$ days interval, $\mathrm{F}_{4}-5$ days interval, $\mathrm{F}_{5}-4$ days interval

Table 2 (a): Effect of different mulches and fertigation scheduling on yield parameters of turmeric

\begin{tabular}{|c|c|c|c|c|c|c|c|c|c|c|c|c|c|c|c|}
\hline \multirow[t]{2}{*}{\begin{tabular}{|c|}
$\begin{array}{c}\text { Treatmen } \\
\text { ts }\end{array}$ \\
\end{tabular}} & \multicolumn{3}{|c|}{$\begin{array}{c}\text { Number of mother rhizome } \\
\text { plant }^{-1}\end{array}$} & \multicolumn{3}{|c|}{$\begin{array}{c}\text { Number of fingers } \\
\text { plant }^{-1}\end{array}$} & \multicolumn{3}{|c|}{$\begin{array}{c}\text { Length of mother } \\
\text { rhizome }\end{array}$} & \multicolumn{3}{|c|}{$\begin{array}{c}\text { Length of primary } \\
\text { fingers }\end{array}$} & \multicolumn{3}{|c|}{\begin{tabular}{|c}
$\begin{array}{c}\text { Girth of mother rhizome } \\
(\mathrm{cm})\end{array}$ \\
\end{tabular}} \\
\hline & 2017-18 & 2018-19 & Pooled & $\begin{array}{c}2017- \\
18\end{array}$ & $\begin{array}{c}2018- \\
19\end{array}$ & $\begin{array}{c}\text { Poole } \\
\text { d }\end{array}$ & 2017-18 & 2018-19 & Pooled & $2017-18$ & 2018-19 & Pooled & $2017-18$ & 2018-19 & Pooled \\
\hline \multicolumn{16}{|c|}{ Different mulches (M) } \\
\hline $\mathrm{M}_{1}$ & 1.17 & 1.23 & 1.20 & 9.04 & 11.40 & 10.22 & 7.70 & 7.92 & 7.81 & 7.78 & 8.68 & 8.23 & 5.05 & 5.55 & 5.30 \\
\hline $\mathrm{M}_{2}$ & 1.48 & 1.63 & 1.55 & 11.15 & 13.81 & 12.48 & 9.03 & 9.55 & 9.29 & 8.86 & 9.88 & 9.37 & 5.54 & 5.81 & 5.67 \\
\hline $\mathrm{M}_{3}$ & 1.25 & 1.43 & 1.34 & 10.33 & 12.49 & 11.41 & 8.70 & 8.93 & 8.82 & 8.30 & 9.27 & 8.79 & 5.52 & 5.60 & 5.56 \\
\hline$F^{\prime}$ test & Sig. & Sig. & Sig. & Sig. & Sig. & Sig. & Sig. & Sig. & Sig. & Sig. & Sig. & Sig. & NS & NS & NS \\
\hline $\mathrm{SE}(\mathrm{m}) \pm$ & 0.02 & 0.04 & 0.02 & 0.18 & 0.19 & 0.11 & 0.21 & 0.13 & 0.16 & 0.2 & 0.2 & 0.2 & 0.12 & 0.11 & 0.08 \\
\hline $\mathrm{CD}$ at $5 \%$ & 0.1 & 0.14 & 0.06 & 0.7 & 0.73 & 0.43 & 0.83 & 0.51 & 0.63 & 0.79 & 0.8 & 0.77 & - & - & - \\
\hline
\end{tabular}




\begin{tabular}{|c|c|c|c|c|c|c|c|c|c|c|c|c|c|c|c|}
\hline \multicolumn{16}{|c|}{ Fertigation scheduling (F) } \\
\hline $\mathrm{F}_{1}$ & 1.11 & 1.20 & 1.16 & 8.87 & 11.18 & 10.03 & 7.93 & 8.17 & 8.05 & 7.69 & 8.23 & 7.96 & 4.98 & 5.53 & 5.26 \\
\hline $\mathrm{F}_{2}$ & 1.22 & 1.29 & 1.26 & 9.47 & 11.98 & 10.72 & 8.15 & 8.60 & 8.38 & 7.77 & 8.77 & 8.27 & 5.40 & 5.69 & 5.55 \\
\hline $\mathrm{F}_{3}$ & 1.28 & 1.42 & 1.35 & 10.56 & 12.69 & 11.62 & 8.37 & 8.75 & 8.56 & 8.32 & 9.45 & 8.88 & 5.42 & 5.53 & 5.47 \\
\hline $\mathrm{F}_{4}$ & 1.49 & 1.67 & 1.58 & 11.11 & 13.76 & 12.43 & 9.11 & 9.39 & 9.25 & 9.07 & 10.19 & 9.63 & 5.61 & 5.76 & 5.69 \\
\hline $\mathrm{F}_{5}$ & 1.39 & 1.56 & 1.47 & 10.87 & 13.24 & 12.06 & 8.83 & 9.08 & 8.96 & 8.73 & 9.76 & 9.24 & 5.43 & 5.74 & 5.59 \\
\hline$F^{\prime}$ test & Sig. & Sig. & Sig. & Sig. & Sig. & Sig. & Sig. & Sig. & Sig. & Sig. & Sig. & Sig. & NS & NS & $\mathrm{NS}$ \\
\hline $\mathrm{SE}(\mathrm{m}) \pm$ & 0.06 & 0.08 & 0.05 & 0.34 & 0.42 & 0.12 & 0.25 & 0.23 & 0.15 & 0.3 & 0.4 & 0.23 & 0.16 & 0.18 & 0.14 \\
\hline $\mathrm{CD}$ at $5 \%$ & 0.2 & 0.25 & 0.18 & 1.12 & 1.36 & 0.39 & 0.81 & 0.76 & 0.5 & 0.98 & 1.3 & 0.76 & - & - & - \\
\hline \multicolumn{16}{|c|}{ Interaction (M X F) } \\
\hline$F^{\prime}$ test & NS & NS & NS & NS & NS & NS & NS & NS & NS & NS & NS & NS & NS & NS & NS \\
\hline $\mathrm{SE}(\mathrm{m}) \pm$ & 0.08 & 0.14 & 0.06 & 0.78 & 0.73 & 0.57 & 0.4 & 0.41 & 0.3 & 0.47 & 0.46 & 0.29 & 0.2 & 0.24 & 0.16 \\
\hline $\mathrm{CD}$ at $5 \%$ & - & - & - & - & - & - & - & - & - & - & - & - & - & - & - \\
\hline
\end{tabular}

$\mathrm{M}_{1-}$ Control (without mulch), $\mathrm{M}_{2}$-Soybean straw mulch, M3-Silver polythene mulch, F1-Control (100\% RDF through soil application), $\mathrm{F}_{2}-15$ days interval, $\mathrm{F}_{3}-8$ days interval, $\mathrm{F}_{4}-5$ days interval, $\mathrm{F}_{5}-4$ days interval

Table 2 (b): Effect of different mulches and fertigation scheduling on yield parameters of turmeric

\begin{tabular}{|c|c|c|c|c|c|c|c|c|c|c|c|c|}
\hline Treatments & \multicolumn{3}{|c|}{ Girth of primary fingers $(\mathrm{cm})$} & \multicolumn{3}{|c|}{ Yield plant $^{-1}(\mathrm{~g})$} & \multicolumn{3}{|c|}{ Yield (q/ha) } & \multicolumn{3}{|c|}{ Dry matter plant $^{-1}(\mathrm{~g})$} \\
\hline & $2017-18$ & 2018-19 & Pooled & 2017-18 & 2018-19 & Pooled & 2017-18 & 2018-19 & Pooled & 2017-18 & 2018-19 & Pooled \\
\hline \multicolumn{13}{|c|}{ Factor A-Different mulches (M) } \\
\hline $\mathrm{M}_{1}$ & 4.04 & 4.29 & 4.16 & 338.78 & 377.74 & 358.26 & 250.94 & 279.81 & 265.38 & 23.76 & 24.72 & 24.24 \\
\hline $\mathrm{M}_{2}$ & 4.23 & 4.71 & 4.47 & 423.46 & 489.10 & 456.28 & 313.68 & 362.29 & 337.98 & 31.23 & 33.99 & 32.61 \\
\hline $\mathrm{M}_{3}$ & 4.21 & 4.53 & 4.37 & 375.08 & 433.16 & 404.12 & 277.84 & 320.86 & 299.35 & 27.04 & 29.37 & 28.20 \\
\hline$F^{\prime}$ test & NS & NS & NS & Sig. & Sig. & Sig. & Sig. & Sig. & Sig. & Sig. & Sig. & Sig. \\
\hline $\mathrm{SE}(\mathrm{m}) \pm$ & 0.08 & 0.21 & 0.13 & 15.79 & 13.54 & 7.36 & 11.7 & 10.03 & 5.46 & 0.53 & 0.88 & 0.57 \\
\hline CD at $5 \%$ & - & - & - & 62.01 & 53.16 & 28.92 & 45.93 & 39.38 & 21.42 & 2.07 & 3.45 & 2.22 \\
\hline \multicolumn{13}{|c|}{ Factor B -Fertigation scheduling (F) } \\
\hline $\mathrm{F}_{1}$ & 3.97 & 4.41 & 4.19 & 327.24 & 367.89 & 347.57 & 242.40 & 272.51 & 257.46 & 22.70 & 24.88 & 23.79 \\
\hline $\mathrm{F}_{2}$ & 4.22 & 4.45 & 4.33 & 355.88 & 413.07 & 384.47 & 263.61 & 305.98 & \begin{tabular}{|l|}
284.79 \\
\end{tabular} & 24.85 & 27.32 & 26.08 \\
\hline $\mathrm{F}_{3}$ & 4.13 & 4.47 & 4.30 & 376.99 & 439.91 & 408.45 & 279.25 & 325.86 & 302.56 & 27.16 & 29.21 & 28.18 \\
\hline $\mathrm{F}_{4}$ & 4.32 & 4.69 & 4.51 & 426.32 & 482.02 & 454.17 & 315.79 & 357.05 & 336.42 & 32.71 & 34.55 & 33.63 \\
\hline $\mathrm{F}_{5}$ & 4.16 & 4.52 & 4.34 & 409.11 & 463.77 & 436.44 & 303.04 & 343.53 & 323.29 & 29.31 & 30.84 & 30.08 \\
\hline$F^{\prime}$ test & NS & NS & NS & Sig. & Sig. & Sig. & Sig. & Sig. & Sig. & Sig. & Sig. & Sig. \\
\hline $\mathrm{SE}(\mathrm{m}) \pm$ & 0.15 & 0.19 & 0.12 & 15.3 & 14.37 & 10.62 & 11.34 & 10.64 & 7.87 & 1.36 & 1.6 & 1.22 \\
\hline $\mathrm{CD}$ at $5 \%$ & - & - & - & 49.9 & 46.85 & 34.63 & 36.97 & 34.7 & 25.65 & 4.44 & 5.22 & 3.98 \\
\hline \multicolumn{13}{|c|}{ Interaction (M X F) } \\
\hline$F^{\prime}$ test & $\mathrm{NS}$ & NS & NS & Sig. & Sig. & Sig. & Sig. & Sig. & Sig. & NS & NS & $\mathrm{NS}$ \\
\hline $\mathrm{SE}(\mathrm{m}) \pm$ & 0.24 & 0.31 & 0.13 & 13.08 & 15.77 & 11.87 & 9.69 & 11.68 & 8.79 & 2.25 & 1.79 & 1.5 \\
\hline $\mathrm{CD}$ at $5 \%$ & - & - & - & 39.21 & 47.28 & 35.58 & 29.05 & 35.02 & 26.36 & - & - & - \\
\hline
\end{tabular}

$\mathrm{M}_{1-}$ Control (without mulch), $\mathrm{M}_{2}$-Soybean straw mulch, $\mathrm{M}_{3}$-Silver polythene mulch, F1-Control (100\% RDF through soil application), $\mathrm{F}_{2}-15$ days interval, $\mathrm{F}_{3}-8$ days interval, $\mathrm{F}_{4}-5$ days interval, $\mathrm{F}_{5}-4$ days interval

\section{Effect of fertigation scheduling \\ Growth parameters}

The growth parameters included plant height (at 180 DAP), number of leaves plant ${ }^{-1}$ (at 120 DAP), leaf area (at 180 DAP), and number of tillers plant ${ }^{-1}$ at harvest. The observation recorded on growth parameters is given in table 1 . The data revealed significant differences among the treatments for plant height, leaf area, and the number of tillers plant $^{-1}$. Significantly maximum plant height, leaf area, and the number of tillers plant ${ }^{-1}$ was recorded in $\mathrm{F}_{4}$ i.e. 30 splits with 5 days interval through fertigation @ 80\% RDF $(97.73 \mathrm{~cm}$, $254.76 \mathrm{~cm}^{2}$, and 1.83 , respectively) and was at par with the treatment $\mathrm{F}_{5}$ i.e. 40 splits with 4 days interval through fertigation@80\% RDF. However, significantly minimum plant height, leaf area, and the number of tillers plant ${ }^{-1}$ was registered in $F_{1}$ i.e. control $(100 \%$ RDF through soil application).

Frequent application at 5 day intervals increases nutrient availability leads to increases in $\mathrm{N}, \mathrm{P}$ and $\mathrm{K}$ absorption during the growth period, which increases protein and protoplasm synthesis for a higher rate of mitosis, increases height of the plant and the number of tillers plant ${ }^{-1}$. Leaf area was significantly influenced by fertigation schedules. Higher leaf area in treatment 5 days interval might be due to the increased photosynthetic capacity of plants in this treatment as evidenced by higher leaf area, due to the continuous availability to nitrogen, phosphorus, and potassium through the drip system. Similar results have been reported by Prabhakara et al. (2010) ${ }^{[19]}$ in green chilli.

The data revealed significant differences among the treatments in respect number of leaves plant ${ }^{-1}$. A significantly maximum number of leaves plant ${ }^{-1}$ was recorded in $\mathrm{F}_{4}$ i.e. 30 splits with 5 days interval through fertigation@80\% RDF (17.96) which was significantly superior over the rest of all the treatments. This was followed by treatment $F_{5}$ i.e. 40 splits with 4 days interval through fertigation @ 80\%. However, the significantly minimum number of leaves plant ${ }^{-1}$ was registered in $\mathrm{F}_{1}$ i.e. control $(100 \%$ RDF through soil application). This may be due to the frequent and increasing use of fertilizers directly in the vicinity of the root zone, which increases the availability and absorption of nutrients, which leads to an increase in cell size and elongation of the cell leading to healthy and vigorous plant growth as well as an increase in the number of leaves plant ${ }^{-1}$.

\section{Yield parameters}

The experimental finding indicated that different fertigation scheduling was significantly influenced the yield parameters [Table 2 (a) and 2 (b)]. Significantly maximum number mother rhizome and fingers plant ${ }^{-1}$ (1.58 and 12.43), length of 
mother rhizome and primary fingers $(9.25 \mathrm{~cm}$ and $9.63 \mathrm{~cm})$, yield plant $^{-1}(454.17 \mathrm{~g})$, yield/ ha (336.42 q), and dry matter plant $^{-1}(33.63 \mathrm{~g})$ was recorded in $\mathrm{F}_{4}$ i.e. 30 splits with 5 days interval through fertigation @ 80\% RDF and was at par with the treatment $\mathrm{F}_{5}$ i.e. 40 splits with 4 days interval through fertigation@ @ 80\% RDF. However, significantly minimum number mother rhizome and fingers plant ${ }^{-1}$, length of mother rhizome and primary fingers, yield plant ${ }^{-1}$, yield (q/ha), and dry matter plant ${ }^{-1}$ was registered in $\mathrm{F}_{1}$ i.e. control (100\% RDF through soil application).

Among the fertigation schedules, $\mathrm{F}_{4}$ i.e. 30 splits with 5 days interval through fertigation @ 80\% RDF exhibited significantly maximum yield and yield attributes of turmeric. The extent of increase in yield ( $\mathrm{q} / \mathrm{ha}$ ) was 30.66 percent over the treatment control (100\% RDF through soil application). This could be due to the continuous division of nutrients during the growing period of the crops which improved the growth attributes accompanied by more physiological activities and absorbed PAR reflected in a higher photosynthetic rate and in the translocation of nutrients towards the reproductive part increasing the yield and yield attributes. Similar results were found by Singh et al. (2013) [22].

\section{Interaction effect}

Data presented in table 3. Interaction between different mulches and fertigation scheduling was found non- significant in respect to all growth parameters except the number of leaves plant ${ }^{-1}$ and all yield parameters non- significant except yield plant ${ }^{-1}$ and yield (q/ha). In respect of growth parameters, the maximum number of leaves plant $^{-1}(21.15)$ was recorded in treatment combination $\mathrm{M}_{2} \mathrm{~F}_{4}$ i.e. soybean straw mulch +30 splits with 5 days interval through fertigation@ @ 80\% RDF which was significantly superior to the rest of all the treatment combinations. This was followed by treatment combinations $\mathrm{M}_{2} \mathrm{~F}_{5}, \mathrm{M}_{3} \mathrm{~F}_{4}$, and $\mathrm{M}_{2} \mathrm{~F}_{3}$. However, significantly minimum numbers of leaves plant ${ }^{-1}$ (12.04) were observed by the treatment combination $\mathrm{M}_{1} \mathrm{~F}_{1}$ i.e. control (without mulch) + control (100\% RDF through soil application).

In respect of yield parameters, maximum yield plant ${ }^{-1}$ (523.32 g) and yield (387.64 q/ha) were recorded in treatment combination $\mathrm{M}_{2} \mathrm{~F}_{4}$ i.e. soybean straw mulch +30 splits with 5 days interval through fertigation @ 80\% RDF recorded and was at par with the treatment combination $\mathrm{M}_{2} \mathrm{~F}_{5}$. However, the significantly minimum yield plant ${ }^{-1}(328.70 \mathrm{~g})$ and yield/ ha $(243.48 \mathrm{q})$ were recorded by the treatment combination $\mathrm{M}_{1} \mathrm{~F}_{1}$ i.e. control (without mulch) + control (100\% RDF through soil application).

Table 3: Interaction effect of different mulches and fertigation scheduling on growth and yield parameters of turmeric

\begin{tabular}{|c|c|c|c|c|c|c|c|c|c|}
\hline \multirow{2}{*}{ Treatment combinations } & \multicolumn{3}{|c|}{ Number of leaves plant ${ }^{-1}$ at 120 DAP } & \multicolumn{3}{|c|}{ Yield plant $^{-1}$} & \multicolumn{3}{|c|}{ Yield (q/ha) } \\
\hline & 2017-18 & 2018-19 & Pooled & 2017-18 & 2018-19 & Pooled & 2017-18 & 2018-19 & Pooled \\
\hline \multicolumn{10}{|c|}{ Different mulches (M) X Fertigation Scheduling } \\
\hline $\mathrm{M}_{1} \mathrm{~F}_{1}$ & 11.13 & 12.95 & 12.04 & 314.24 & 343.16 & 328.70 & 232.77 & 254.19 & 243.48 \\
\hline $\mathrm{M}_{1} \mathrm{~F}_{2}$ & 12.98 & 13.63 & 13.31 & 327.30 & 367.13 & 347.22 & 242.45 & 271.95 & 257.20 \\
\hline $\mathrm{M}_{1} \mathrm{~F}_{3}$ & 13.59 & 14.60 & 14.09 & 338.59 & 380.95 & 359.77 & 250.81 & 282.18 & 266.50 \\
\hline $\mathrm{M}_{1} \mathrm{~F}_{4}$ & 13.91 & 17.05 & 15.48 & 362.32 & 412.11 & 387.22 & 268.39 & 305.27 & 286.83 \\
\hline $\mathrm{M}_{1} \mathrm{~F}_{5}$ & 13.69 & 16.93 & 15.31 & 351.42 & 385.36 & 368.39 & 260.31 & 285.45 & 272.88 \\
\hline $\mathrm{M}_{2} \mathrm{~F}_{1}$ & 14.14 & 14.33 & 14.24 & 343.16 & 394.52 & 368.84 & 254.19 & 292.24 & 273.22 \\
\hline $\mathrm{M}_{2} \mathrm{~F}_{2}$ & 14.73 & 16.87 & 15.80 & 400.47 & 447.57 & 424.02 & 296.65 & 331.54 & 314.09 \\
\hline $\mathrm{M}_{2} \mathrm{~F}_{3}$ & 14.87 & 18.26 & 16.56 & 438.57 & 487.93 & 463.25 & 324.87 & 361.43 & 343.15 \\
\hline $\mathrm{M}_{2} \mathrm{~F}_{4}$ & 19.67 & 22.63 & 21.15 & 479.54 & 567.09 & 523.32 & 355.21 & 420.07 & 387.64 \\
\hline $\mathrm{M}_{2} \mathrm{~F}_{5}$ & 16.31 & 18.92 & 17.62 & 455.57 & 548.37 & 501.97 & 337.46 & 406.20 & 371.83 \\
\hline $\mathrm{M}_{3} \mathrm{~F}_{1}$ & 12.45 & 13.27 & 12.86 & 324.34 & 365.97 & 345.16 & 240.25 & 271.09 & 255.67 \\
\hline $\mathrm{M}_{3} \mathrm{~F}_{2}$ & 12.80 & 14.10 & 13.45 & 339.85 & 424.50 & 382.17 & 251.74 & 314.44 & 283.09 \\
\hline $\mathrm{M}_{3} \mathrm{~F}_{3}$ & 14.34 & 17.82 & 16.08 & 353.82 & 450.87 & 402.34 & 262.09 & 333.97 & 298.03 \\
\hline $\mathrm{M}_{3} \mathrm{~F}_{4}$ & 15.92 & 18.60 & 17.26 & 437.09 & 466.85 & 451.97 & 323.77 & 345.82 & 334.79 \\
\hline $\mathrm{M}_{3} \mathrm{~F}_{5}$ & 14.57 & 18.41 & 16.49 & 420.33 & 457.59 & 438.96 & 311.35 & 338.95 & 325.15 \\
\hline$F^{\prime}$ test & Sig. & Sig. & Sig. & Sig. & Sig. & Sig. & Sig. & Sig. & Sig. \\
\hline $\mathrm{SE}(\mathrm{m}) \pm$ & 0.57 & 0.64 & 0.45 & 13.08 & 15.77 & 11.87 & 9.69 & 11.68 & 8.79 \\
\hline $\mathrm{CD}$ at $5 \%$ & 1.70 & 1.93 & 1.35 & 39.21 & 47.28 & 35.58 & 29.05 & 35.02 & 26.36 \\
\hline
\end{tabular}

$\mathrm{M}_{1}$ - Control (without mulch), $\mathrm{M}_{2}$-Soybean straw mulch, $\mathrm{M}_{3}$-Silver polythene mulch, $\mathrm{F}_{1}$-Control (100\% RDF through soil application), $\mathrm{F}_{2}-15$ days interval, $\mathrm{F}_{3}-8$ days interval, $\mathrm{F}_{4}-5$ days interval, $\mathrm{F}_{5}-4$ days interval [e.g. $\mathrm{M}_{1} \mathrm{~F}_{1}-\mathrm{M}_{1}-$ Control (without mulch) $+\mathrm{F}_{1}-\mathrm{Control}(100 \% \mathrm{RDF}$ through soil application)]

\section{Acknowledgment}

The authors would like to acknowledge all the staff and friends from the Department of Horticulture, Dr. PDKV, Akola for their help during this investigation.

\section{References}

1. Anonymous. Area and production of turmeric in India, Anony-mous, 2017. http://www.indiastat.com

2. Banker MC, Mane MC, Khade KK, Kanjie ST. Comparative performance of drip vs conventional method of irrigation on banana. Proc. All India Symp. Sprinkler, Drip irrigation, 1993, 89-92p.

3. Chandra R, Sheo G. Effect of mulching on yield of ginger (Zingiber officinale Rosc.) J. Spices and Aromatic Crops. 2001; 10(1):13-16.
4. Dubey AK, Singh AK. Response of turmeric (Curcuma longa L.) to split doses and time of nitrogen application under mid altitude of Arunachal Pradesh. Progressive Hort 2004;36:245-248.

5. Elfving DC. Crop response to trickle irrigation. Hort. Rev 1982;4:1-48.

6. Gill BS, Randhawa RS, Randhawa GS, Singh J. Response of turmeric (Curcuma longa L.) to nitrogen in relation to application farmyard manure and straw mulch. J. Spices and Aromatic Crops 1999;8:211-214.

7. Gupta CR, Awasthi OP. Effect of mulch material on growth and yield of ginger (Zingiber officinale Rosc.). Veg. Sci 1997;24(1):13-15.

8. Haynes RJ. Fert. Res 1985;6:235-255. 
9. Indulekha VP, Thomas CG. Utilization of water hyacinth as mulch in turmeric. J Tropical Agri 2018;56(1):27-33.

10. Jalota SK, Prihar SS. Reducing soil water evaporation with tillage and mulching. Iowa State University Press, Ames, 1998, 142p.

11. Junior MA, Borella JC, Franca SC, Masca MGCC. Effects of type of rhizome used to proliferation and mulching on growth and productivity of turmeric (Curcuma longa L.). Revista Brasileira-de-plants Med 2005;8:30-34.

12. Kaur A, Brar AS. Influence of mulching and irrigation scheduling on productivity and water use of turmeric (Curcuma longa L.) in north-western India. Irrig. Sci 2016;34:261-269.

13. Kay BL. Mulch and chemical stabilizers for land reclamation in dry regions. In: Schaller FW, Sutten $\mathrm{P}$ (eds) Reclamation of drastically disturbed lands. American Society of Agronomy, Madison, 1978, 467$483 \mathrm{p}$.

14. Kumar D, Pandey V, Nath V. Effect of organic mulches on moisture conservation for rainfed turmeric production in mango orchard. Indian J. Soil Conserv 2008;36:188191.

15. Kushwah SS, Dwivedi YC, Jain PK. Effect of mulching materials on growth and yield attributes and enhancing farm income through ginger cultivation under rainfed rice-based production. Veg. Sci 2013;40(1):96-98.

16. Manhas SS. Effect of different cultural practices on growth and yield of turmeric (Curcuma longa L.) Ph. D. Thesis, Punjab Agricultural University, Ludhiana, Punjab (India), 2009.

17. Mohanty DC, Sharma Y, Panda BS. Influence of mulch materials and ground covers on the yield of turmeric under rainfed condition in Orissa. Indian Cocoa, Arecanut and Spices J 1991;14:97-99.

18. Philip J, Sethumadhavan P, Vidhyadharan KK. Turmeric cultivation an appraisal of agronomic practices. Indian Farmer Dig 1981;14:19-21.

19. Prabhakara BN, Ramchandrappa BK, Nanjappa HV, Soumya TM. Effect of frequency and methods of fertigation on growth, yield, quality, and economics of green chilli (Capsicum annum L.). Mysore J Agric. Sci 2010;44:523-28.

20. Rair ABS, Chhina GS, Chatha HS. Response of turmeric (Curcuma longa L.) to plant architecture and mulching in terms of growth and rhizomes yield in Punjab. Prog. Agric 2011;11(2):450-452.

21. Roy AR, Wamanan PP. Influence of mulch on growth and yield of ginger (Zingiber officinale). Environment and Ecology 1988;6(3):630-632.

22. Singh A, Gulati IJ, Chopra R. Effect of various fertigation schedule and organic manures on tomato (Lycopersicon esculentum Mill.) yield under arid condition. J Life sciences 2013;8(4):1261-1264.

23. Singh J, Randhawa GS. Effect of intercropping on yield and quality of turmeric. Acta Hortic 1988;18:183-186.

24. Singh PS, Singh GD, Singh AB. Effect of mulching, spacing, and intercropping of green gram (Vigna radiate) on growth, yield, and quality of turmeric (Curcuma longa L.). Int. J Agril. Sci 2016;12(1):90-94.

25. Singh $\mathrm{S}$. The effect of partial shading on the growth and yield of turmeric. M.sc Thesis, Punjab Agricultural University, Ludhiana, 1992.

26. Srimal RC. Turmeric: a brief review of medicinal properties. Fitoterapia 1997;68:483-493.
27. Swain SC, Rath S, Ray DP. Effect of NPK levels and mulching on growth, yield and economics of turmeric in rainfed uplands. Orissa J Hort 2007;35:58-60. 